\title{
Effects of light quality and irradiance level interactions on short-term pigment response of the red alga Corallina elongata
}

\author{
Patricia Algarra*, Gloria de la Viña, Javier Niell \\ Departamento de Ecología, Facultad de Ciencias, Universidad de Málaga, Campus de Teatinos, E-29071, Málaga, Spain
}

\begin{abstract}
Effects of interactions between light quality and irradiance level were tested on photosynthetic pigments of the red intertidal alga Corallina elongata Ellis et Soland. During a short-term accommodation process $(0$ to $5 \mathrm{~h}$ ), pigments adapted chromatically to light quality. R-phycoerythrin and R-phycocyanin increases were induced under green light at $180 \mu \mathrm{mol} \mathrm{m} \mathrm{m}^{-2} \mathrm{~s}^{-1}$ In contrast, chlorophyll a increased only under red light at the same irradiance level. In an energy-limited situation, at an irradiance $\left(20 \mu \mathrm{mol} \mathrm{m} \mathrm{m}^{-2} \mathrm{~s}^{-1}\right)$ close to the photosynthetic compensation point of $\mathrm{C}$. elongata, the accommodation process was inhibited and no chromatic response was detected. The use of antibiotics (rifamycin and chloramphenicol) that inhibit chloroplastic protein synthesis revealed that red light acts on phycobiliprotein synthesis in the same way as antibiotics that suppress transcription and translation. The short-term accommodation process involves 'de novo' synthesis of phycobiliproteins. The mechanism of pigment accommodation is discussed in the frame of chromatic adaptation theory.
\end{abstract}

\section{INTRODUCTION}

The ability to alter pigment composition according to the quality of ambient light is called chromatic adaptation. This phenomenon has been rigorously demonstrated to occur in cyanobacteria (Fujita \& Hattori 1962, Bennett \& Bogorad 1973, Bogorad 1975, Haury \& Bogorad 1977. Tandeau de Marsac 1977). In other phyla, the situation is unclear, because chromatic adaptation has been studied from an ecological point of view, with the aim of relating pigment content to photosynthetic rates and to vertical distribution of benthic macrophytes. The existence of chromatic adaptation in macrophytes is unlikely because white light at low irradiance induces the same pigment increase as monochromatic light at the same irradiance, independently of its spectral distribution (Ramus et al. 1977 , Rhee \& Briggs 1977, Dring 1981, Ramus 1983, Ramus \& Van der Meer 1983).

In cyanobacteria chromatic adaptation to light quality has generally been tested at an irradiance not limiting to growth. In this way, Tandeau de Marsac (1983)

\footnotetext{
- Address for correspondence: Botanisches Institut der Universität München, Menzingerstr. 67, W-8000 München 19 , Germany
}

described 3 groups of cyanobacteria according to their capacity to adapt or not chromatically, focusing study only on biliprotein synthesis.

In the present study, chromatic response of photosynthetic pigments in the intertidal red algae Corallina elongata Ellis et Soland was tested with red and green light at low irradiance levels: at the photosynthetic compensation point of the studied species, and at an irradiance below the onset of photosynthetic saturation (see 'Materials and methods'). High green irradiance was not used because, as argued by Ramus (1983), seaweeds never encounter this situation in the field.

The responses were studied on a short-term scale 10 to $5 \mathrm{~h}$ ), and have already been described in relation to irradiance (Algarra \& Niell 1990). They are of particular interest because they represent proof of the ability of seaweeds to adapt to rapid changes in environmental conditions.

It is known that phycobiliprotein polypeptides are encoded in chloroplast DNA, and these genes have been isolated and sequenced in prokaryotic cyanobacteria (Conley et al. 1986, Mazel et al. 1986, 1988). In order to detect if this rapid response (which could be called accommodation) is controlled at the chloroplast genetic level, antibiotics that inhibit this protein synthesis were used, and the phycobiliprotein response tested. 


\section{MATERIALS AND METHODS}

Specimens of a shade morphotype (mean maximum irradiance in the field, $450 \pm 54 \mu \mathrm{mol} \mathrm{m}{ }^{-2} \mathrm{~s}^{-1}$ ) of the red algae Corallina elongata Ellis et Soland were harvested from the rocky shores of 'Punta Carnero' in the bay of Algeciras (southern Spain). The plants were incubated for 24 h at $15^{\circ} \mathrm{C}$ under cool-white fluorescent lamps at an irradiance of $600 \mu \mathrm{mol} \mathrm{m} \mathrm{m}^{-2} \mathrm{~s}^{-1}$ (Licor model SPM, Quantum SPQ AO521 radiometer) in order to decrease pigment concentration prior to the application of the different treatments

Light sources. Green and red light were provided by 2 fluorescent lamps, green and red respectively (Silvania F20W/G and Silvania F20W/R). Spectra were determined with a spectroradiometer (Licor 1800-UW) and are presented in Fig. 1. The quantum irradiances chosen were $20 \mu \mathrm{mol} \mathrm{m} \mathrm{m}^{-2} \mathrm{~s}^{-1}$ (the photosynthetic compensation point of the studied species) and $180 \mu \mathrm{mol}$ $\mathrm{m}^{-2} \mathrm{~s}^{-1}$, a low irradiance between the compensation point and $I_{k}$ (the onset of saturation; for this morphotype $340 \mu \mathrm{mol} \mathrm{m}{ }^{-2} \mathrm{~s}^{-1}$ ) (Algarra 1986).

Experimental design. Samples (4 g) of plants were introduced into aquaria containing $600 \mathrm{ml}$ of filtered seawater (Whatman GF/C) under constant air flow and temperature $\left(18 \pm 1^{\circ} \mathrm{C}\right)$. Nutrient depletion and consequent damage to the pigment pool was avoided by adding $5 \mu \mathrm{M} \mathrm{NO} \mathrm{NO}_{3}^{-}$to the incubation batches. Three samples (total plants) were taken at $0,0.5,1,2,3$ and 5 h. At $5 \mathrm{~h}$ pigment concentrations were constant as reported previously (Algarra \& Niell 1990).

The first set of experiments was carried out under the described light qualities, at both irradiance levels. In order to detect the existence of genetic control, 2 antibiotics which suppress the synthesis of proteins in the chloroplast were used in the second set: rifamycin and chloramphenicol which act at the transcription and the translation level, respectively. The effective doses were 0.24 and $12.12 \mu \mathrm{g} \mathrm{ml}^{-1}$, for rifamycin and chloramphenicol, respectively. The antibiotics were added to separate batches under green light at $180 \mu \mathrm{mol} \mathrm{m} \mathrm{m}^{-2} \mathrm{~s}^{-1}$. Two controls, under both red and green light at 180 umol m $\mathrm{m}^{-2} \mathrm{~s}^{-1}$, were used as references.
Pigment determination. Phycobiliproteins were extracted in parallel on triplicate samples by grinding in phosphate buffer $(0.1 \mathrm{M}, \mathrm{pH} 6.5)$ at $4{ }^{\circ} \mathrm{C}$. The homogenate was then centrifuged (Beckman, Rotor JA21, $45000 \times g, 0.5 \mathrm{~h}$ ). The equations of Rosenberg (1981) were used to calculate the concentrations of Rphycoerythrin (PE) and R-phycocyanin (PC).

Chlorophyll a (chl a) samples were extracted, in triplicate samples, by grinding the alga in $100 \%$ acetone saturated with $\mathrm{MgCO}_{3}$. The extinction coefficient of Talling \& Driver (1963) was used to calculate chl a concentrations.

The relationship between the different pigments was calculated using the number of chromophores according to Algarra \& Niell (1990).

Data were tested with a model I, 1-way or 2-way ANOVA and also with non-parametric KolmogorovSmirnov and $\chi^{2}$ tests. Differences where $p<0.05$ were taken as significant.

\section{RESULTS}

Results obtained after submitting the specimens to different light qualities and irradiance levels are presented in Fig. 2. PE and PC concentrations increased under green light and decreased under red light. ChI a behaved in the opposite way, increasing under red light and decreasing under green light. These effects were detected only at $180 \mathrm{\mu mol} \mathrm{m}^{-2} \mathrm{~s}^{-1}$. At the compen-

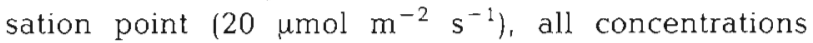
obtained after $5 \mathrm{~h}$ of light treatments were lower than initial ones.

The increase or decrease of pigment concentrations was clearly evident after $5 \mathrm{~h}$ of exposure. However it is interesting to examine how the mechanism of accommodation takes place. At $180 \mu \mathrm{mol} \mathrm{m} \mathrm{m}^{-2} \mathrm{~s}^{-1}$, where the light treatment induced a final decrease of pigment concentration, the pattern of accommodation was a rapid increase of concentrations followed by inhibition. This occurred in all cases: PE and PC under red light and $c h l a$ under green light. On the other hand, under conditions that induced pigment increase, the response was slower and continuous.
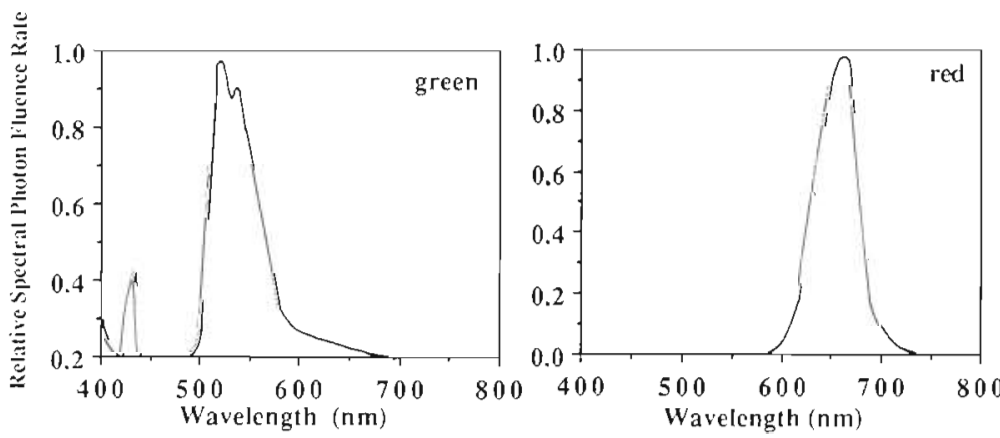

Fig. 1. Relative spectral photon fluence rate of light sources used in experiments 
Fig. 2. Corallina elongata. Variations of R-phycoerythrin (PE), R-phycocyanin (PC) and chlorophyll a (chl a) concentrations $\left(\mathrm{g}^{-1} \mathrm{dry} w \mathrm{t}\right)$ as a function of time (h) under green and red light at (-) $180 \mu \mathrm{mol} \mathrm{m} \mathrm{m}^{-2} \mathrm{~s}^{-1}$ and $\left(\right.$ (口) $20 \mu \mathrm{mol} \mathrm{m} \mathrm{m}^{-2} \mathrm{~s}^{-1}$ Means \pm standard deviation $(\mathrm{n}=3$ )
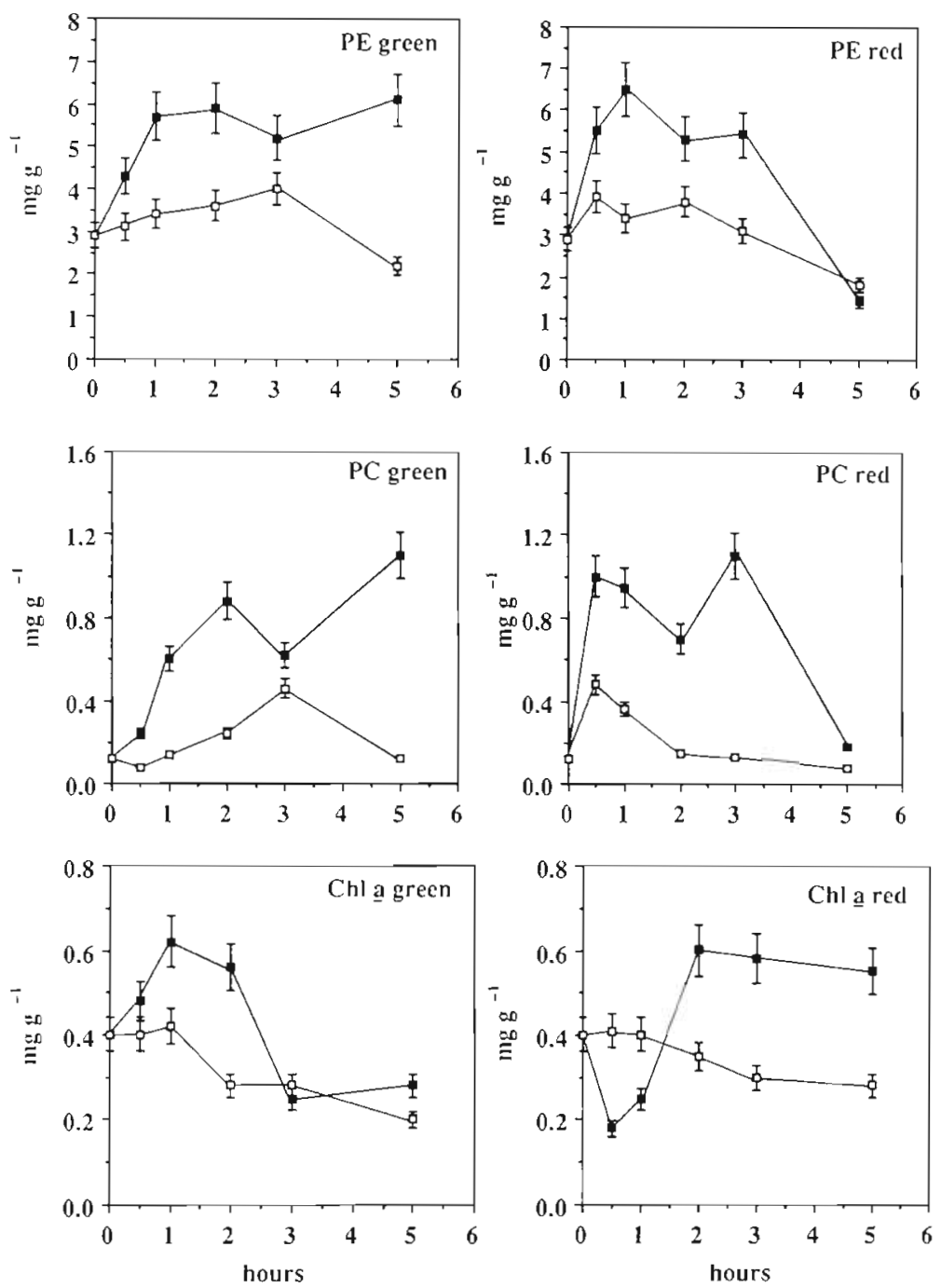

Table 1 Corallina elongata. R-phycoerythrin (PE), R-phycocyanin (PC) and chlorophyll a (chl a) concentrations (no. of chromophores $\times 10^{16} \mathrm{~g}^{-1}$ dry $w \mathrm{t}$ ) and ratios between the different pigments, obtained after $5 \mathrm{~h}$ of light treatments. Means \pm standard deviation $(n=3)$. IC: initial conditions

\begin{tabular}{|c|c|c|c|c|c|}
\hline \multirow[b]{2}{*}{ PE } & \multirow{2}{*}{ 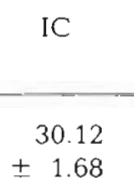 } & \multicolumn{2}{|c|}{$\begin{array}{c}\text { Red light Green light } \\
\left(180 \mu \mathrm{mol} \mathrm{m} \mathrm{m}^{-2} \mathrm{~s}^{-1}\right)\end{array}$} & \multicolumn{2}{|c|}{$\begin{array}{l}\text { Red light Green light } \\
\left(20 \mu \mathrm{mol} \mathrm{m}-2 \mathrm{~s}^{-1}\right)\end{array}$} \\
\hline & & $\begin{array}{r}12.13 \\
\pm \quad 1.20\end{array}$ & $\begin{array}{r}50.16 \\
\pm \quad 5.99\end{array}$ & $\begin{array}{r}14.56 \\
\pm \quad 0.80\end{array}$ & $\begin{array}{r}25.88 \\
+\quad 2.71\end{array}$ \\
\hline PC & $\begin{array}{r}0.82 \\
\pm \quad 0.08\end{array}$ & $\begin{array}{r}0.84 \\
\pm \quad 0.09\end{array}$ & $\begin{array}{r}5.60 \\
\pm \quad 0.58\end{array}$ & $\begin{array}{r}0.28 \\
+\quad 0.02\end{array}$ & $\begin{array}{r}0.78 \\
\pm \quad 0.05\end{array}$ \\
\hline Chl a & $\begin{array}{r}20.31 \\
\pm \quad 2.72\end{array}$ & $\begin{array}{r}33.01 \\
\pm \quad 2.54\end{array}$ & $\begin{array}{r}16.82 \\
+\quad 1.53\end{array}$ & $\begin{array}{r}16.86 \\
\pm \quad 0.91\end{array}$ & $\begin{array}{r}12.01 \\
\pm \quad 1.32\end{array}$ \\
\hline $\mathrm{PE} / \mathrm{chl} a$ & $\begin{array}{r}1.48 \\
\pm \quad 0.05\end{array}$ & $\begin{array}{r}0.36 \\
\pm \quad 0.04\end{array}$ & $\begin{array}{r}2.98 \\
+\quad 0.41\end{array}$ & $\begin{array}{r}0.87 \\
\pm \quad 0.09\end{array}$ & $\begin{array}{r}2.15 \\
+\quad 0.03\end{array}$ \\
\hline $\mathrm{PC} / \mathrm{chl} a$ & $\begin{array}{ll} & 0.04 \\
\pm & 0.005\end{array}$ & $\begin{array}{ll} & 0.02 \\
\pm & 0.002\end{array}$ & $\begin{array}{ll} & 0.33 \\
\pm & 0.052\end{array}$ & $\begin{array}{ll} & 0.02 \\
\pm & 0.003\end{array}$ & $\begin{array}{ll} & 0.06 \\
\pm & 0.002\end{array}$ \\
\hline $\mathrm{PE} / \mathrm{PC}$ & $\begin{array}{r}36.73 \\
\pm \quad 1.50\end{array}$ & $\begin{array}{r}14.44 \\
\pm \quad 1.02\end{array}$ & $\begin{array}{r}8.95 \\
\pm \quad 1.02\end{array}$ & $\begin{array}{r}52.01 \\
\pm \quad 7.80\end{array}$ & $\begin{array}{r}33.17 \\
\pm \quad 2.51\end{array}$ \\
\hline
\end{tabular}



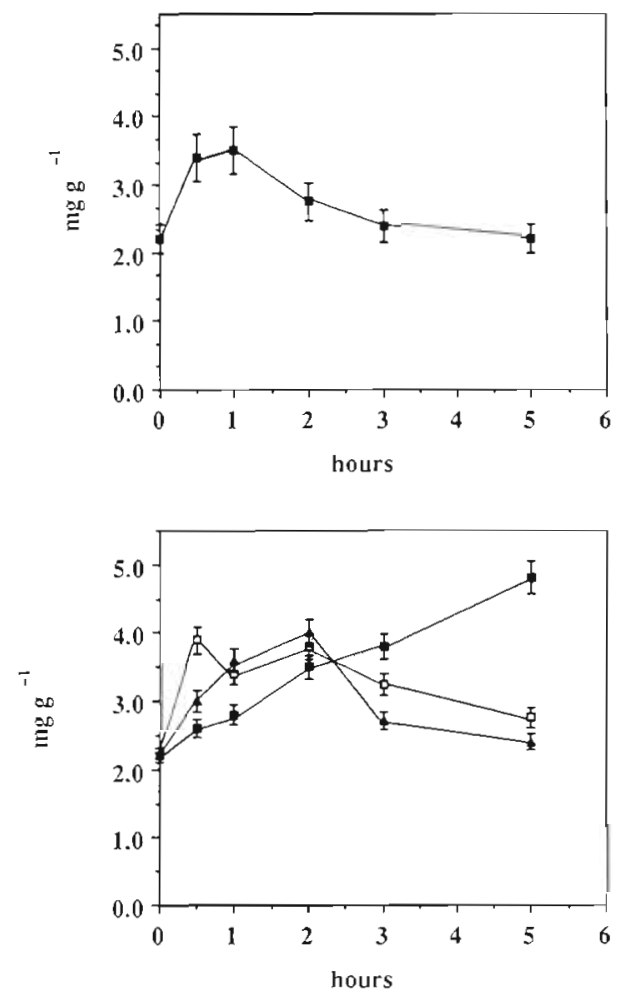

Fig. 3. Corallina elongata. Variations of R-phycoerythrin (PE) concentrations $\left(\mathrm{g}^{-1} \mathrm{dry} \mathrm{wt}\right)$. Upper: under red light $(180 \mu \mathrm{mol}$ $\left.\mathrm{m}^{-2} \mathrm{~s}^{-1}\right)$; lower: under green light $\left(180 \mu \mathrm{mol} \mathrm{m} \mathrm{m}^{-2} \mathrm{~s}^{-1}\right)$ : (口) without antibiotics; ( $\square$ ) with $0.24 \mu \mathrm{g} \mathrm{m}^{-1}$ of rifamicyn; ( $\Delta$ ) with $12.12 \mu \mathrm{g} \mathrm{ml}^{-1}$ of chloramphenicol. Means \pm standard deviation $(\mathrm{n}=3)$

At irradiance corresponding to the compensation point, the accommodation process was drastically inhibited.

Table 1 lists concentrations and ratios between the different pigments obtained after $5 \mathrm{~h}$ of exposure to the different treatments. The ratios $\mathrm{PE} / \mathrm{chl}$ a and $\mathrm{PC} / \mathrm{chl} a$ were significantly higher under green than red light at both irradiance levels used. However these data have to be regarded with caution because the apparent chromatic accommodation detected at the compensation point is not due to an increase of phycobiliproteins in green light. This is probably caused by a differential rate of pigment degradation in this energy-limited situation. The $\mathrm{PE} / \mathrm{PC}$ ratio was higher under red than green light due to the higher increase or decrease of PC related to $\mathrm{PE}$.

In the second set of experiments (Figs. 3 \& 4), using antibiotics which suppress protein synthesis at the chloroplast level, clear and significant inhibitions of PE and $\mathrm{PC}$ were detected after $3 \mathrm{~h}$ of treatment under green light. Both antibiotics, rifamycin and chloramphenicol, had the same effect. It is interesting that in the first $2 \mathrm{~h}$ in the treatments with antibiotics a significantly greater increase of biliproteins was registered
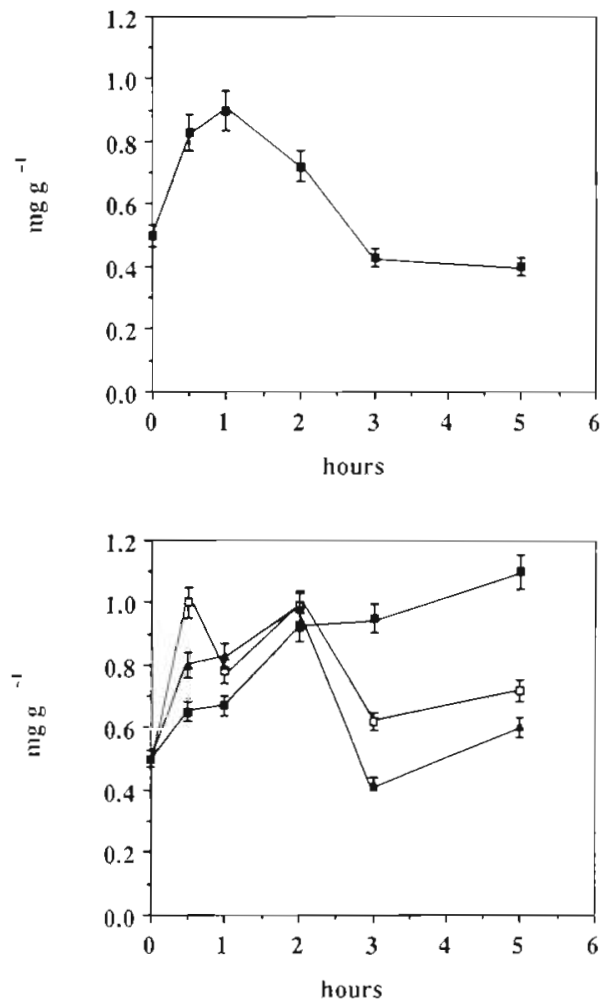

Fig. 4. Corallina elongata. Variations of R-phycocyanin (PC) concentrations $\left(\mathrm{g}^{-1}\right.$ dry $\left.\mathrm{wt}\right)$. Upper: under red light $(180 \mu \mathrm{mol}$ $\mathrm{m}^{-2} \mathrm{~s}^{-1}$; lower: under green light $\left(180 \mu \mathrm{mol} \mathrm{m} \mathrm{m}^{-2} \mathrm{~s}^{-1}\right)$ : ( ) without antibiotics; ( $\square$ ) with $0.24 \mathrm{~kg} \mathrm{ml}^{-1}$ of rifamicyn; ( 1 ) with $12.12 \mu \mathrm{g} \mathrm{ml}^{-1}$ of chloramphenicol. Means \pm standard deviation $(n=3)$

than in the green control. A similar increase was detected in the red control. In fact the response obtained with antibiotics under green light was not significantly different to that obtained under red light without antibiotics.

\section{DISCUSSION}

The theory of complementary chromatic adaptation (Engelmann 1882) has long been argued, discussed and studied from different points of view Chromatic adaptation has been tested in algae taking into account the light regime (quality and intensity) where algae live (macrophytes), and from a more strictly physiological and biochemical point of view, with light quality not only restricted to low photon fluence.

This paper considers only interactions between light quality and irradiance level, taking into account where the algae live. For this reason only photon fluxes were chosen in the low range, according to the photosynthetic parameters of the studied species. Green light in the field is not related only to depth. In caespitose algae like Corallina elongata, light is filtered by the canopy 
which shifts it to the green spectral zone (Holmes \& Smith 1977). In C. elongata the apical portion of the plant possesses a lower $\mathrm{PE} / \mathrm{chl}$ a ratio than the central part of the canopy (Algarra \& Niell 1987). In consequence, inside the canopy the spectral distribution of photon fluence is not only reduced in irradiance but also shifted to the green spectral zone. This is probably the typical field situation. Algae are very seldom submitted to a monochromatic spectral narrowband, and more probably to a spectral distribution enriched in one or another color.

The present data reveal that a very close interaction exists between light quality and irradiance level. Green light induces phycobiliprotein synthesis only when the photon fluence used does not involve an energylimited situation, which occurs at irradiance close to the photosynthetic compensation point. The same occurs with chl a under red light. This irradiance level switching effect under monochromatic light has been described in higher plants for the synthesis of lightharvesting complexes and their mRNA (Eskins et al. 1989). The effect has been described independently of the possible involvement of photoreceptors on pigment synthesis. Such involvement has been proposed in red algae (Lopez-Figueroa \& Niell 1989, Lopez-Figueroa et al. 1989b) and a phytochrome-like protein has even been detected in Corallina elongata using monoclonal antibodies (Lopez-Figueroa et al. 1989a). Nevertheless, the identification of these photoreceptors is still not established.

Besides the involvement of photoreceptors, the main controversy about pigment adaptation of macrophytes lies in the dilemma 'intensity' adapters or 'chromatic' adapters. Ramus (1983), working at low irradiance (13 $\% I_{0}$ ) on Gracilaria tikvahiae McLachlan and Grinnellia americana (C.Ag.) Harvey, detected the same pigment increase under white light as under green light. Beer \& Levy (1983), working at irradiance close to the compensation point on Gracilaria sp., did not detect chromatic adaptation. No attempt is made here to discuss these results, but rather to contribute to the interesting problem of pigment adaptation. It has to taken into account that not all species behave alike and that they live in very different conditions in the field. Chromatic adaptation has been demonstrated to occur in cyanobacteria on the basis of review of more than 100 strains of different species (Tandeau de Marsac 1983). For red algae, we do not have the same culture facilities, and we usually work with algae brought from the field. Therefore far fewer species have been studied compared with cyanobacteria. As in that phylum the capacity for chromatic adaptation does not have to occur in all species, and certainly not always in the same way. In fact, in the shade morphotype of Corallina elongata studied in this paper, PC synthesis was induced by green and not by red light as opposed to that usually occurring in group III chromatic adapters of cyanobacteria (Tandeau de Marsac 1983). In these cyanobacteria PC synthesis is lowered under green light but never completely arrested. More studies are necessary to build a chromatic adaptation theory, similar to that for cyanobacteria, in red algae. On the other hand, it is necessary to consider that photosynthetic response not only depends on pigment concentrations and ratios but also on other factors like the morphology of the algae, the optical transparency, the growth rate (Ramus 1983) and the activity of all the enzymes related to the photosynthetic process.

Another aspect is the scale of study of the phenomenon. The term adaptation is usually used on the temporal scale of geologic time or ontogenetic scale. Shortterm responses due to rapid changes of environmental variables are considered as physiological accommodation involving no changes in the genome (Levy \& Gantt 1988). The present data strengthen those obtained in a previous work (Algarra \& Niell 1990). Conditions that induce pigment inhibition (red light for phycobiliproteins and green light for chl a) enhance an oscillatory process prior to accommodation. A similar result was detected under high irradiance for phycobiliproteins and low irradiance for chl a (Algarra \& Niell 1990). It is interesting that the oscillation detected under red light on phycobiliproteins is similar to that detected with antibiotics under green light. That suggests that red light acts at the same level as rifamycin and chloramphenicol: transcription and translation in the chloroplast respectively.

It is known for cyanobacteria that light quality regulates phycobiliprotein synthesis at the transcriptional and post-transcriptional level (Gendel et al. 1979, Grossmann et al. 1988, Tandeau de Marsac et al. 1988, Oelmüller et al. 1989). Gendel et al. (1979) detected the decay of PE synthesis within 45 min under red light, after application of rifamycin. Oelmüller et al. (1989) detected that the accumulation of phycobiliprotein mRNA is also inhibited by chloramphenicol within 10 min. In a red algae like Corallina elongata, the inhibition is detected only after $3 \mathrm{~h}$. In an eucaryotic alga the regulation process of pigment synthesis is probably more complex. Cooperative interactions between nuclear and cytoplasmic genomes must control the synthesis of phycobilisome components (Egelhoff \& Grossman 1983, Kursar et al. 1983). This problem requires further research at different levels (physiology, biochemistry and molecular biology). Nevertheless, it is interesting to note in this work that, in algae brought from the field, the short-term phycobiliprotein accommodation process in response to environmental changing conditions seems to be controlled at the genetical level. 
Acknowledgements. This work was supported by the Junta de Andalucia' project no 12710.

\section{LITERATURE CITED}

Algarra, P. (1986). Mecanismos y respuestas adaptativas a corto plazo del equipo pigmentario de dos morfotipos de Corallina elongata Ellis et Soland. Tesis doctoral, Univ. de Mălaga

Algarra, P., Niell, F. X. (1987). Structural adaptations to light reception in two morphotypes of Corallina elongata Ellis et Soland. P.S.Z.N. I: Mar. Ecol. 8: 253-261

Algarra, P., Niell, F. X. (1990). Short-term pigment response of Corallina elongata Ellis et Soland to light intensity Aquat. Bot. 36: 127-138

Beer, S., Levy, I. (1983). Effects of photon fluence rate and light spectrum composition on growth, photosynthesis and pigment relations in Gracilaria sp. J. Phycol. 19: 516-522

Bennett, A., Bogorad, L. (1973). Complementary chromatic adaptation in a filamentous blue-green alga. J. Cell Biol. 58: $419-435$

Bogorad, L. (1975). Phycobiliproteins and complementary chromatic adaptation. Ann. Rev. Plant. Physiol. 26: 369-401

Conley, P. B., Lemaux, P. G., Lomax, T. L., Grossman, A. R. (1986). Genes encoding major light-harvesting polypeptides are clustered on the genome of the cynobacterium Fremeyella diplosiphon. Proc. natl. Acad. Sci. USA 83: $3924-3928$

Dring, M. J. (1981). Chromatic adaptation of photosynthesis in benthic marine algae: an examination of its ecological significance using a theoretical model. Limnol. Oceanogr. 26: $271-284$

Egelhoff, R. K., Grossman, A. (1983). Cytoplasmic and chloroplastic synthesis of phycobilisomes polypeptides. Proc. natl. Acad. Sci. USA 80: 291-301

Engelmann, T W (1882). Über Sauerstoffausscheidung von Pflanzzellen im Mikrospektrum. Bot. Zeitung 40: 419-426

Eskins, K., Westhoff, P., Berenand, P. D. (1989). Light quality and irradiance level interaction in the control of expression of light-harvesting complex of photosystem II: Plant Physiol. 91 163-169

Fujita, Y., Hattori, A. (1962). Photochernical interconversion between precursors of phycobilins chromoproteids in Tolypothrix tenuis. Plant Cell Physiol 3: 209-220

Gendel, S., Ohad, I., Bogorad, L. (1979). Control of phycoerythrin synthesis during chromatic adaptation. Plant Physiol. 64: 786-790

Grossman, A. R., Lemaux, P. G., Bruns, U. B., Anderson, L. K. (1988). Characterization of phycobiliprotein and linker polyptide genes in Fremyella diplosiphon and their regulated expression during complementary chromatic adaptation. Photosynthesis Res. 17: 23-56

Haury, J. F., Bogorad, L. (1977). Action spectra for phycobiliprotein synthesis in a chromatically adapting cyanophyte. Plant Physiol. 60: 835-839

Holmes, M. G., Smith, H. (1977). The function of phytochrome in the natural environment. II The influence of vegetation canopies on the spectral energy distribution of natural daylight. Photochem. Photobiol. 25: 539-545

Kursar, T. A., Van der Meer, J., Alberte, R. S. (1983). Light-

This article was submitted to the editor harvesting system of the red alga Gracilaria tikvahiae. II Phycobilisome characteristics of pigment mutants. Plant Physiol. 73: 361-369

Levy, I., Gantt, E. (1988). Light acclimatation of Porphyridium cruentum: growth, photosynthesis and phycobilisomes. $I$. Phycol. 24: 452-458

Lopez-Figueroa, F., Niell, F. X. (1989). Red light and blue light regulation photoreceptors controlling chlorophyll a synthesis in the red alga Porphyra umbilicalis and in the green alga Ulva rigida. Physiol. Plant. 76: 391-397

Lopez-Figueroa, F., Lindemann, P., Braslavsky, S. E., Schaffner, K., Schneider-Portsch, H. A. W., Rüdiger, W. (1989a). Detection of a phytochrome-like protein in macroalgae. Bot. Acta 102: 178-180

Lopez-Figueroa, F., Perez, R., Niell, F. X. (1989b). Effects of red and far-red light pulses on the chlorophyll and biliprotein accumulation in the red alga Corallina elongata. $J$. Photochem. Photobiol., B.: Biology 4: 185-193

Mazel, D., Houmard, J., Sidler, W., Bryant, D. A., Tandeau de Marsac, N. (1986). Green light induces transcription of the phycoerythrin operon in the cyanobacterium Calothrix 7601 Nucleic Acids Res. 14: 8279-8290

Mazel, D., Houmard, J., Tandeau de Marsac, N. (1988). A multigene family in Calothrix sp. PCC 7601 encodes phycocyanin, the major component of the cyanobacterial light harvesting antenna. Molec. gen. Genetics 211; 296-304

Oelmüller, R., Grossman, A. R., Briggs, W R. (1989). Role of protein synthesis in regulation of phycobiliprotein mRNA abundance by light quality in Fremyella diplosiphon. Plant. Physiol. 90: 1486-1491

Ramus, J. (1983). A physiological test of the theory of complementary chromatic adaptation. II Brown, green and red seaweeds. J. Phycol. 19: 173-178

Ramus, J., Lemons, F., Zimmerman, C. (1977). Adaptation of light-harvesting pigments to downwelling light and the consequent photosynthetic performance of the eulittoral rockweeds Ascophyllum nodosum and Fucus vesiculosus. Mar. Biol. 42: 293-303

Ramus, J., Van der Meer, J. P. (1983). A physiological test of the theory of complementary chromatic adaptation. I. Color mutants of a red seaweed. J. Phycol. 19: 86-91

Rhee, C., Briggs, W. R. (1977). Some responses of Chondrus crispus to light. I. Pigmentation changes in the natural habitat. Physiol. Plant. 43: 35-42

Rosenberg, G. (1981). Ecological growth strategies in the seaweeds Gracilaria foliffera (Rhodophyceae) and Ulva sp. (Chlorophyceae). Ph. D. thesis, Yale University

Talling, J. F., Driver, D. (1963). Some problems in the estimation of chlorophyll a in phytoplankton. In: Proceedings of a Conference on Primary Productivity Measurement. Marine \& Freshwater. Atomic Energy, Comm. Tid., Hawaii, USA. 7633: $142-146$

Tandeau de Marsac, N. (1977). Occurrence and nature of chromatic adaptation in cyanobacteria. J. Bacteriol. 130 : 201-254

Tandeau de Marsac, N. (1983). Phycobilisomes and complementary chromatic adaptation in cyanobacteria. Bull. Inst. Pasteur, Paris 81: 201-254

Tandeau de Marsac, N., Mazel, D., Damerval, T., Gugliemi, G., Capiano, V., Houmard, J. (1988). Photoregulation of gene expression in the filamentous cyanobacterium Calothrix sp. PCC 7601 light-harvesting complexes and cell differentiation. Photosynthesis Res. 18: 99-132

Manuscript first received: August 29, 1990

Revised version accepted: May 7, 1991 